\title{
Cultural Guidelines for Commercial Production of Interiorscape ZZ (Zamioculcas zamiifolia) ${ }^{1}$
}

\author{
Jianjun Chen, Richard J. Henny, and Dennis B. McConnell ${ }^{2}$
}

'ZZ' plant (Zamioculcas zamiifolia), like Aglaonema and Dieffenbachia, is a member of aroid family (Fig. 1). Because of its unique appearance, ability to tolerate low light levels and drought, and resistance to diseases and pests, 'ZZ' is emerging as an important foliage plant for interiorscaping.

Morphologically, 'ZZ' bears little resemblance to any other members of the aroids. It has pinnate leaves and round tapering petioles, and appears similar to the cardboard cycad (Zamia furfuracea), which is why 'ZZ' is also called 'Aroid Palm' or 'Cardboard Palm'. Its naturally glossy leaves are so shiny that the plant appears to have been polished.

'ZZ' is more tolerant of low light levels than other foliage plants, such as Snake Plant (Sansevieria trifasciata) and Cast-iron Plant (Aspidistra elatior). It is easily maintained and adds stalks and new leaves under interior low light environments. Our studies have shown that it can grow and produce new leaves under an interior low light level of 25 foot candles for more than one year. In addition, it can survive without being watered for 3 to 4 months. The drought tolerance is probably due to its waxy and shiny leaves and fleshy stems, which have extremely low rates of transpiration, and its thick rhizomes, which store water. Additionally, few diseases or pests and physiological disorders have been found on this plant in production and interiorscapes. 'ZZ' is the only recognized cultivar in the species. This article is intended to provide brief guidelines for propagation, production, and interior use of 'ZZ'.

\section{Cultural Guides}

\section{Propagation and potting mixes}

Propagation is vegetative using leaf cuttings or division. Single leaflets can be inserted into cells of plug trays filled with a potting medium. Keep the medium moist in a shaded greenhouse under a light level of 1,000 to 1,500 foot candles and a temperature of 75 to $85^{\circ} \mathrm{F}$. For division, the tuber-like rhizomes can be separated and potted.

Commercial potting mixes, such as $60 \%$ sphagnum peat, $20 \%$ perlite, and $20 \%$ vermiculite or $55 \%$ sphagnum peat, $25 \%$ pine bark, and $20 \%$ perlite, can be used for ZZ plant propagation and production. Mixes should have good physical properties and a $\mathrm{pH}$ of 6.0 to 7.0 with an electrical conductivity (EC) of

1. This document is ENH997, a series of the Environmental Horticulture Department, Institute of Food and Agricultural Sciences, University of Florida. Original publication date: December 2004. Reviewed: April 2005. Please visit the EDIS web site at http://edis.ifas.ufl.edu.

2. Jianjun Chen, Associate Professor, Mid-Florida Research and Education Center and Environmental Horticultural Department, Richard J. Henny, Professor, Mid-Florida Research and Education Center and Environmental Horticultural Department, and Dennis B. McConnell, Professor, Environmental Horticultural Department, University of Florida.

The Institute of Food and Agricultural Sciences (IFAS) is an Equal Employment Opportunity - Affirmative Action Employer authorized to provide research, educational information and other services only to individuals and institutions that function without regard to race, creed, color, religion, age, disability, sex, sexual orientation, marital status, national origin, political opinions or affiliations. For information on obtaining other extension publications, contact your county Cooperative Extension Service office. Florida Cooperative Extension Service / Institute of Food and Agricultural Sciences / University of Florida / Larry R. Arrington, Interim Dean 
1.0 to $2.0 \mathrm{dS} / \mathrm{m}(1,000$ to $2,000 \mu \mathrm{mhos} / \mathrm{cm})$ when root-zone solutions are extracted with the pour-through method.

\section{Production}

ZZ should be produced under 80 to $90 \%$ shade or 1,250 to 2,500 foot candles. Production temperature should be kept between 70 to $90^{\circ} \mathrm{F}$ and relative humidity between 50 to $95 \%$. Potting media should remain moist but not wet. Drip or subirrigation is preferable because overhead irrigation leaves water residue on the glossy leaf surfaces and reduces overall plant appearance and marketability. Controlled-release fertilizers $(18.0 \mathrm{~N}-2.6 \mathrm{P}-10.0 \mathrm{~K}$ with micronutrients) at $4,5,8$, or $10 \mathrm{~g}$ can be topdressed to 4-, 6-, 8-, and 10-inch pots, respectively, or water-soluble fertilizers with micronutrients can be used with nitrogen at $200 \mathrm{ppm}$ weekly for drip irrigation or 100 to $150 \mathrm{ppm}$ for sub-irrigation.

$\mathrm{ZZ}$ grows slowly even under the most ideal conditions. We have found that the quantity and size of the rhizomes (Fig. 2) per pot determine the time it takes the plant to grow to marketable size. More rhizomes or larger rhizomes in an appropriately sized pot lead to more shoots and reduce production time. Following the instruction of Table 1 may allow marketable plants to be produced in 8 to 12 months after rhizomes are planted in corresponding pots. Thus, sorting the rhizomes based on sizes and potting them based on size and number will reduce production time and increase profit margins.

\section{Shipping and Interior Care}

Since leaflets of ZZ plants are naturally glossy, no polish is needed. Finished plants are usually placed in paper sleeves and shipped in refrigerated carriers at a temperature between 55 and $65^{\circ} \mathrm{F}$. Once they arrive at the market, plants should be placed under interior light levels of 25 foot candles or higher. Plants produced in 4- to 6-inch pots can be placed on office desks or table tops, but those in 8- or 10-inch pots are best placed on the floor, even in corners where light levels are low. ZZ can also be used as pseudo bonsai or in a combination planter. The average height of most of the plants is about 16 to 32 inches, and the plant may have a wide spread of 20 to 40 inches. Larger plants will have a 3 to 5 feet overall spread. ZZ works well as an accent plant in areas where it can "spread its wings." Plants should not be fertilized if EC readings are $1.0 \mathrm{dS} / \mathrm{m}$ or higher. Media should be kept slightly dry in interior conditions. Temperatures of 68 to $75^{\circ} \mathrm{F}$ are most appropriate. Pot sizes should be increased as the plants grow to provide room for the increased number and size of rhizomes during interiorscapes.

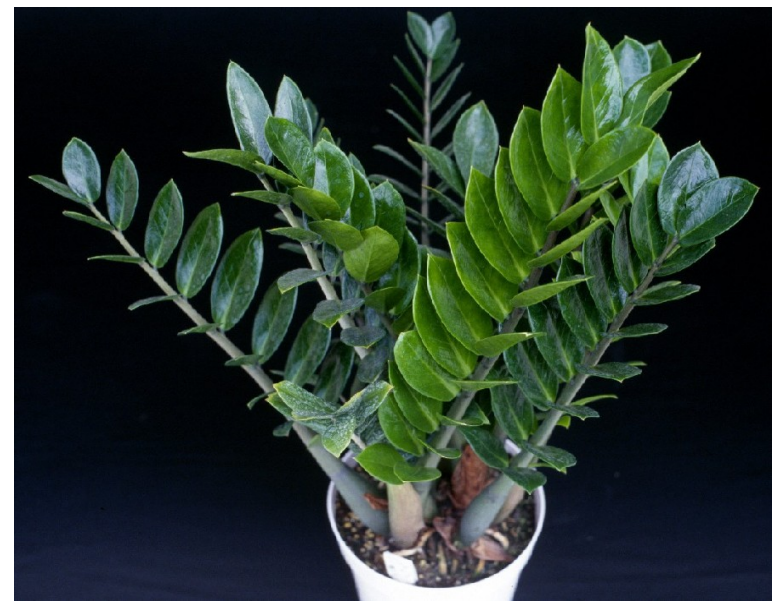

Figure 1. A finished $Z Z$ grown in an 8-inch pot. The Florida Nurserymen and Growers Association named ZZ a 2002 Florida Plant of the Year.

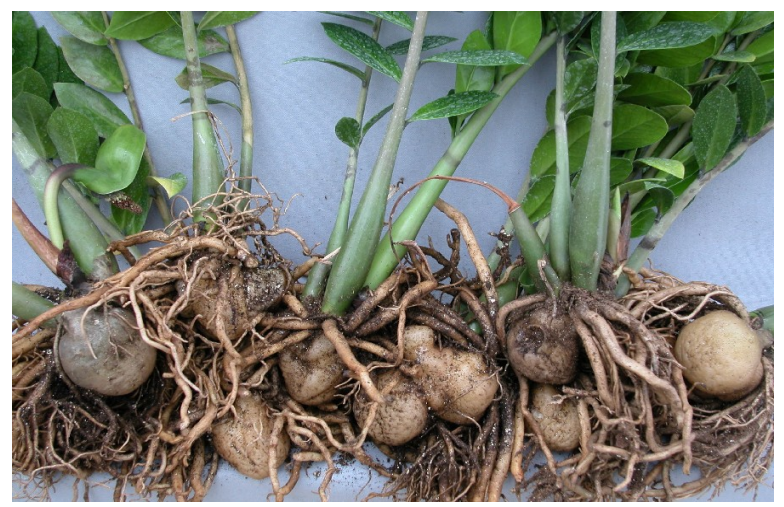

Figure 2. ZZ produces different sizes of rhizomes; rhizome size and the number of rhizomes per pot affect production time. 
Table 1. The size, weight, and quantity of ZZ rhizomes planted in pots for producing marketable plants in 8 to 12 months.

\begin{tabular}{|c|c|c|c|}
\hline Pot size & $\begin{array}{l}\text { Rhizome size } \\
\text { (Length } \times \text { Width) }\end{array}$ & $\begin{array}{c}\text { Rhizome weight } \\
\text { (grams) }\end{array}$ & $\begin{array}{l}\text { Rhizomes per pot } \\
\text { (No.) }\end{array}$ \\
\hline 4 inches & 0.8 inches $\times 0.8$ inches & $4-5$ & $2-3$ \\
\hline \multirow[t]{2}{*}{6 inches } & 0.8 inches $\times 0.8$ inches & $4-5$ & $4-5$ \\
\hline & 1.6 inches $\times 1.0$ inches & $10-15$ & $2-3$ \\
\hline \multirow[t]{2}{*}{8 inches } & 1.6 inches $x 1.0$ inches & $10-15$ & $3-4$ \\
\hline & 2.0 inches $\times 1.5$ inches & $30-40$ & $2-3$ \\
\hline 10 inches & 2.0 inches $\times 1.5$ inches & $30-40$ & $3-4$ \\
\hline
\end{tabular}

